\title{
Sediment research, management and policy
}

\author{
A decade of JSS
}

\author{
Ulrich Förstner • Wim Salomons
}

Received: 12 October 2010 / Accepted: 13 October 2010/Published online: 6 November 2010

(C) Springer-Verlag 2010

\section{Introduction}

Sediment is an essential part of water systems. It provides the substrate for organisms, and after naturally occurring flooding, sediment is left as a deposit of fertile silt on flood plains. At the same time, sediment acts as a potential sink for many hazardous chemicals. Where water quality is improving, the legacy of the past may still be present in sediment hidden at the bottom of rivers, behind dams, in lakes, estuaries, seas and on floodplains. Unlike problems related to conventional polluted sites, the risks here are primarily connected with the transportation and deposition of contaminated solids in catchment areas, especially in downstream regions.

This overview reports on sediment issues in the first decade of the EU Water Framework Directive (WFD) and the European demand-driven sediment research network, SedNet. One of the most challenging sites for the remediation of historically contaminated sediment, the Bitterfeld floodplain, will be revisited 10 years after the first international case comparison at ConSoil 2000. Our Journal of Soils and Sediments (JSS) is celebrating its 10th anniversary; however, its roots go back to an ambitious publication series of the

\footnotetext{
U. Förstner $(\bowtie)$

Institute of Environmental Technology and Energy Economics, Hamburg University of Technology (TUHH),

Eissendorfer Str. 40,

21071 Hamburg, Germany

e-mail: u.foerstner@tu-harburg.de

W. Salomons $(\bowtie)$

Kromme Elleboog 21,

9751 RB Haren (Gn), Netherlands

e-mail: wim.salomons@home.nl

International Association of Sediment-Water Science starting in the 1970s (Petticrew 2009).

\section{Ten years of sediment issues bridging science and policy in Europe}

"The EU Water Framework Directive is probably the most significant legislative instrument in the water field that was introduced on an international basis for many years. It moves towards integrated environmental management with key objectives to prevent any further deterioration of water bodies, and protect and enhance the status of aquatic ecosystems and associated wetlands. It aims to promote sustainable water consumption and will contribute to mitigating the effects of floods and droughts" (Quevauviller et al. 2008; sediment monitoring issues see, e.g., Ahlf et al. 2008; Förstner et al. 2008).

SedNet, the European demand-driven sediment research network, has played a key role in addressing problems with contaminated sediments at the river-basin scale. SedNet was funded in the wider context of the European Water Framework Directive by EC Directorate-General Research from January 2002 to December 2004 under the 5th Framework Programme for Research, Technology Development and Demonstration (Anonymous 2001a), and-now as the "European Sediment Network"-continues as a private initiative since 2005 (www.sednet.org/). SedNet activities were accompanied from the beginning by the JSS, based on an association agreement between SedNet and Almut Heinrich, JSS Managing Editor at Ecomed Publisher, Landsberg (Germany). 
Expectations of the politics may be partly reflected in the early JSS article by DG Research (Quevauviller 2001). The researchers' views on the new tasks under the WFD are presented in the SedNet book (Salomons and Brils 2004) and the overall paradigm shift during the initial researchoriented period can be followed best in the JSS Editorial of Tiedo Vellinga (Vellinga 2004).

Specific research and management issues were addressed by four dedicated SedNet Work Packages (Anonymous 2004a, which formed the basis of the four volumes on Sustainable Management of Sediment Resources (Owens 2008; Barcelo and Petrovic 2006; Bortone 2006; Heise 2007) and represented in the four sediment sections in JSS up to volume 10 (2010).

\subsection{Sediment management-from site-specific to river-basin view}

Sediment assessment is the characterization of sediments for a given purpose (e.g. evaluation for risks to environmental health, habitat construction, etc.). Sediment management is about making decisions and taking actions on sediments; it seeks balance between (a) minimising contaminant risk in the environment and human health and (b) minimising costs (Apitz and Power 2002).

Risk assessment is an integral part of risk management (Ellen et al. 2007): Risk indicators are necessary tools to connect risks with management options for sites and river basin (Table 1). They can help simplify complex information, can be used for site prioritisation or site-specific ranking, and can thus trigger management actions (Joziasse et al. 2007).

The Conceptual Site Model is a three-dimensional description of a site representing the knowledge on the contaminant source area(s), as well as the physical, chemical, and biological processes that affect contaminant transport from the source(s) through site environmental media to potential receptors. A basin-scale assessment involves the balancing of a Conceptual Basin Model, which considers the mass flows of particles and contaminants, screening level assessment of sediment quality (and archived data), and basin-scale objectives to generate a Basin Use Plan (Apitz and White 2003).

- In practice, a manager may enter the process after source control, at a site-specific scale, or at the basin scale, respectively. The monitoring at the initial stages is to inform on prioritizations and decisions, and during the later stages of the process to assess the outcome of the action and the associated feedback mechanisms for further assessment and action if required (Apitz et al. 2007).

- Key information for a Conceptual (River) Basin Model includes the identification of sources of sediment, the pathways of sediment and contaminants within and between the various environments, and the role of storage elements (Owens 2005).

In the river systems, globally, large reservoirs such as flood plains and lakes intercept between $25 \%$ and $30 \%$ of the sediment and consequently there are impacts on coastal wetlands and coastal morphology. In estuaries, the composition of sediments is determined by the mixture of marine sediments supplied from the coast and the supply by rivers. Natural tracers and different scenarios can be used to predict mixing ratios of marine to fluvial sediments in estuaries, and hence their contamination. The results show, for example, even for a "green" scenario, that sediment quality in the Rhine catchment will pose future problems due to the temporary storage of contaminants in soils and sediment (Salomons 2005).

A recent thematic issue of the Journal of Soils and Sediments (Owens et al. 2010) assembled seven examples

Table 1 Risk indicators and management options for sites and river basins (Joziasse et al. 2007)

\begin{tabular}{|c|c|c|c|}
\hline \multicolumn{2}{|l|}{ Indicators of risk } & \multicolumn{2}{|l|}{ Management options } \\
\hline Site-specific & River basin & Site-specific & River basin \\
\hline High contaminant load & Indicators for habitat losses & In situ treatment & $\begin{array}{l}\text { Negotiations with upstream/ } \\
\text { downstream stakeholders }\end{array}$ \\
\hline Ecotoxicological effects & $\begin{array}{l}\text { High contamination of } \\
\text { waters and sediments }\end{array}$ & Capping & $\begin{array}{l}\text { Make use of established river } \\
\text { commissions (ICPR) }\end{array}$ \\
\hline $\begin{array}{l}\text { Alteration of benthic } \\
\text { community }\end{array}$ & $\begin{array}{l}\text { Poor chemical and physico- } \\
\text { chemical quality }\end{array}$ & Function change & $\begin{array}{l}\text { Revisions of industrial or agricultural } \\
\text { policies; enforcement of regulations }\end{array}$ \\
\hline Eutrophication & Reduction migrating species & $\begin{array}{l}\text { Turn to river basin management } \\
\text { (source control) }\end{array}$ & \\
\hline $\begin{array}{l}\text { High number of } E \text {. coli or } \\
\text { pathogens }\end{array}$ & & $\begin{array}{l}\text { Sediment basins, dredging, } \\
\text { excavations }\end{array}$ & \\
\hline
\end{tabular}

$I C P R$ International Commission for the Protection of the Rhine (example) 
for quality and quantity aspects. Key issues associated with sediment quantity included:

- In a global view, human activities and disturbances probably have a greater influence on erosion rates and sediment transport in rivers than climate changes (Slaymaker 2010);

- in the northern Ethiopian highlands, due to the majority of sediment export occurring during a few intense flash flood events, it is necessary to reduce sediment yield at the medium-sized catchment scale, i.e. to mitigate high water flows in channels as well as hillslope erosion rates (Vanmaercke et al. 2010);

- in the Trinity River (Texas) modern fluvial sediment input to the delta is occurring at a rate approximately $20-30 \%$ of the mean Holocene accretion rate, which is insufficient to combat subsidence and wetland loss and keep pace with the future sea level rise (Slattery et al. 2010);

- in the Rhine Delta, the many proposed landscaping measures against the potential combined effects of climate and land use changes will considerably rehabilitate the natural role of the floodplains as traps for fluvial sediment conveyed from the continents to the coastal zone (Middelkoop et al. 2010).

The editors conclude that one field of research that requires further attention is how catchment areas respond to cumulative effects (Gunn and Noble 2009).

\subsection{Sediment quality issues at the river-basin scale}

Apart from their immediate research and development tasks, SedNet and JSS were also major forces in overcoming widespread ignorance of sediment issues in the initial period of the European Water Framework Directive (Anonymous 2000a):

"The WFD aims at achieving a good ecological potential and good surface water chemical status in European river basins by the year 2015 by a combined approach using emission and pollutant standards. These consider priority pollutants from diffuse and point sources, but neglect the role of sediments as a long-term secondary source of contaminants. Such a lack of information may easily lead to unreliable risk analyses with respect to thepretended-“"good status" (Förstner 2002)

In order to address the requirements of the WFD for quality standards not only in surface water, but also in sediments and biota, SedNet became involved in the working group on Analysis and Monitoring of Priority Substances (AMPS), which considered the technical implications of sediment monitoring (Brils 2004). For the WFD Common Implementation Strategy (CIS), the Scientific Committee on Toxicity, Ecotoxicity and the Environment (Anonymous 2004b) concluded in its report that "specific quality standards can and should be developed for sediment and biota". With regard to the forthcoming programme of measures under WFD (starting in 2009), the Expert Advisory Forum on Priority Substances and Pollution Control (Anonymous 2004c), proposed the specific source/pathway "historical pollution from sediments" (S11.1) for inclusion into an initial step "source screening".

During the contentious discussion in the EU on Environmental Quality Standards (EQS) for sediments it was suggested by SedNet at its Round Table in Venice, November 2006 (Netzband et al. 2007) that EQS should only be regarded as high-level screening values as a start of diagnostics, using different lines of evidence, and linking sediment state to impacts:

"For certain measures (such as source control) target values and a good understanding of the system (different in the upstream and downstream parts) are necessary".

Meanwhile, following the initial under-emphasis by the water authorities and regulatory bodies, sediment issues have developed under the European Framework Directive during the last 5 years (Förstner 2009).

In some river basins of the European Union, sediment issues now dominate the water policy. For example, in the preparation of the River Basin Management Plan of the German Part of the Elbe catchment area the community of those responsible for river-basin management (FGG Elbe) presented a clear statement on the priority aspect "chemical contamination" (http:/ www.fgg-elbe.de/tl_fgg_neu/hintergrundinformationen.html), in that:

- many, if not most, current problems related to suspended matter and sediments, originate from historical contamination;

- outside sources of particle-bound pollutants are the former mining activities and abandoned megasites of the chemical and metal industry;

- within the rivers, long-lasting industrial activities have led to the accumulation of "historically contaminated sediments" in slack water zones or flood plains; and,

- from such deposits, contaminants may be remobilised, e.g. during storm events.

The latter findings can have far-reaching effects on the water quality management in river basins, including monitoring and risk assessment issues. Already minor proportions of contaminated solids when mobilised from historical deposits may dominate the pollutions load in downstream reaches for very long periods of time, and the risk from these sources can 
exceed the short-term danger from dissolved pollutants by orders of magnitude. Therefore, apart from the traditional water EQS considerations under WFD a specific view on these processes and the development of the respective measures is indispensable for a modern water quality management.

\section{Mitigation of large-scale pollutant mobilisation and dispersion in catchments}

\subsection{Mobilisation of pollutants during sediment re-suspension}

Risk assessment at both local and regional scales will require the study of the combined effects of sediment processes during re-suspension, transport and deposition, and the description of these processes by models on different scales for the determination of hydrodynamic, chemical and biological parameters. A broad overview has been presented in the 36 contributions of the book "Sediment Dynamics and Pollutant Mobility in Riversan Interdisciplinary Approach" (Westrich and Förstner 2007); key issues have been identified (Owens and Petticrew 2008), including the important role that microbial activity plays in controlling and regulating sedimentpollutant mobility and transport dynamics, e.g. impacts on sediment stability and sediment flocculation, and the need for continued development of field and laboratory techniques, field sensors and numerical models.
Table 2 presents examples of JSS articles from coordinated research programmes with special emphasis on pollutant remobilisation during flood events.

\subsection{Natural attenuation effects}

While re-suspension of contaminated particles can result in pollutant release into the water phase, sediment-associated contaminants exhibit reduced mobility over time at many sites. Such natural stabilisation effects have been observed, for example, as a consequence of reduced bioavailability of organic and inorganic compounds in soils to biota like earthworms, springtails, nematodes, and microorganisms (Alexander 2000).

The concept of natural attenuation/intrinsic remediation relies on natural processes rather than traditional engineered procedures. Stabilising factors, so-called "diagenetic" or "ageing" effects, which alongside chemical processes directly involving contaminants, include enhanced mechanical consolidation of soil and sediment components by compaction, loss of water and mineral precipitation in pore spaces, may result in a quite significant reduction of the reactivity of solid matrices (Table 3 ).

Natural attenuation processes have played an increasingly important role in the course of the large Swedish Coordinated Project "Mitigation of Environmental Impact from Mining Waste-MiMi", funded by the Swedish Foundation for Strategic Environmental Research (MISTRA 1997-2004; Höglund and Herbert 2004). Initially, natural attenuation was considered a "polishing step" within

Table 2 JSS articles from coordinated research programmes on pollutant remobilization

\begin{tabular}{|c|c|c|c|}
\hline & Programme & Title and Authors & $\begin{array}{l}\text { JSS } \\
\text { number }\end{array}$ \\
\hline $1^{\mathrm{a}}$ & $\begin{array}{l}\text { SEDYMO (Germany, BMBF } \\
\text { 2002-2006) }\end{array}$ & $\begin{array}{l}\text { "Sediment properties for assessing the erosion risk of contaminated riverine sites-a } \\
\text { comprehensive study of covariance patterns over depth in relation to erosion resistance" by } \\
\text { Gerbersdorf et al. (2007) }\end{array}$ & $7: 25-35$ \\
\hline $2^{\mathrm{b}}$ & $\begin{array}{l}\text { ECODIS EU 6th FP 2005- } \\
2008\end{array}$ & $\begin{array}{l}\text { "Redistribution of organic pollutants in river sediments and alluvial soils related to major floods" } \\
\text { by Hilscherova et al. (2007) }\end{array}$ & $\begin{array}{c}7: 167- \\
177\end{array}$ \\
\hline $3^{c}$ & $\begin{array}{l}\text { WELCOME EU 5th FP 2002- } \\
2005\end{array}$ & "Desorption of dieldrin from field-aged sediments: simulating flood events" by Smit et al. (2008) & $8: 80-85$ \\
\hline 4 & $\begin{array}{l}\text { AquaTerra EU 6th FP 2004- } \\
2009\end{array}$ & $\begin{array}{l}\text { "Nonylphenol mass transfer from field-aged sediments and subsequent biodegradation in reactors } \\
\text { mimicking different river conditions" by de Weert et al. (2010) }\end{array}$ & 10:77-88 \\
\hline $5^{\mathrm{e}}$ & $\begin{array}{l}\text { MODELKEY EU 6th FP } \\
2005-2010\end{array}$ & $\begin{array}{l}\text { "Impact of contaminants bound to suspended particulate matter in the context of flood events" by } \\
\text { Wölz et al. (2010) }\end{array}$ & $\begin{array}{l}10: 1174- \\
1185\end{array}$ \\
\hline $6^{\mathrm{f}}$ & $\begin{array}{l}\text { FloodSearch (RWTH } \\
\text { Aachen) }\end{array}$ & $\begin{array}{l}\text { "A combined hydraulic and toxicological approach to assess re-suspended sediments during } \\
\text { simulated flood events. Part I-multiple biomarkers in rainbow trout" by Brinkmann et al. } \\
\text { (2010) }\end{array}$ & $\begin{array}{l}10: 1347- \\
1361\end{array}$ \\
\hline \multicolumn{4}{|c|}{${ }^{a}$ Sediment dynamics and pollutant mobility in rivers } \\
\hline \multicolumn{4}{|c|}{${ }^{\mathrm{b}}$ Dynamic sensing of chemical pollution disasters and predictive modelling of their spread and ecological impact } \\
\hline \multicolumn{4}{|c|}{${ }^{\mathrm{c}}$ Water, environment and landscape management at contaminated megasites } \\
\hline \multicolumn{4}{|c|}{$\begin{array}{l}\text { d Integrated modelling of the river-sediment-soil-groundwater system; advanced tools for the management of catchment areas and river basins in the context } \\
\text { of global change }\end{array}$} \\
\hline
\end{tabular}


Table 3 Demobilisation of pollutants in solid matrices by natural factors (Förstner and Gerth 2001)

\begin{tabular}{ll}
\hline Cause (example) & Effect \\
\hline Compaction & Reduced pollutant... \\
Consolidation & Mobility \\
Phytostabilization (plant roots) & Availability \\
Penetration into dead-end pores & Toxicity \\
Interlayer collapse of clay minerals & Reduction of matrix... \\
Co-precipitation (high-energy sites) & Erodibility \\
Occlusion and over-coating & Permeability \\
Absorption/Diffusion & Reactivity \\
"Diagenesis" & "Natural attenuation" \\
\hline
\end{tabular}

an integrated system of remedial measures (Anonymous 2001b); later it played the role of a passive purification system, to be managed with a minimum of maintenance efforts.

From a conceptual viewpoint it is innovative that MiMi distinguished between prevention and control methods in the near field and natural attenuation processes in the far field (Höglund and Herbert 2004):

- The near field processes include those at the waste deposits and in engineered barriers, e.g. oxygen and water transport, biogeochemical processes in the deposit, the sulphide and iron oxidation and buffer reactions.

- The far-field processes are influenced by geographical, climatic, geological and hydrological factors. The morphology of the target areas and the transport conditions including the effects of hydromechanical factors play a greater role in far-field attenuation processes.

In both cases, focus has been put on passive systems which require a minimum of maintenance; such systems may be part of a natural drainage system (streams, lakes and wetlands), or may consist of constructed ponds and/or wetlands.

Remediation of abandoned surface coal mining sites have been described from world-wide examples by Mudroch et al. (2002); this volume includes a broad overview by Klapper (2002) on low-cost techniques which make use of favourable chemical reactions and biogeochemical processes. Natural attenuation approaches can also be found in the large-scale remediation of the legacies from uranium mining in the former German Democratic Republic (Merkel 2006). During the last 15 years, more than 6 billion EUR have been spent on the former uranium mining areas $\left(300\right.$ million $\mathrm{m}^{3}$ waste heaps, 160 million $\mathrm{m}^{3}$ radioactive sludges) and 10 billion EUR on the restoration of more than 200 open pit coal mines on the middle Elbe basin (Förstner in Heise et al. 2008).
Regarding sediments, monitored natural attenuation is a risk reduction strategy that relies on the evaluation and monitoring of, but minimal interference with the ongoing naturally occurring processes that contain, destroy, or reduce the bioavailability or toxicity of contaminants in sediments to achieve site-specific remedial action objectives (Anonymous 1997). These processes may include biodegradation, biotransformation, bioturbation, diffusion, dilution, adsorption, volatilization, chemical reaction or destruction, re-suspension and burial by clean sediment (Magar et al. 2009; Apitz et al. 2005). Although no action is required to initiate or continue the attenuation process, the selection of monitored natural attenuation as a management strategy is considered the result of a deliberate, thoughtful decision which can only be made following careful site assessment and characterization. Magar and Wenning (2006) suggested "lines of evidence" relating to physical, chemical, and biological processes, which may indicate the potential for monitored natural recovery (MNR):

1. Evidence for contaminant burial and natural deposition with clean sediment over time. The general assessment approach uses vertical contaminant profiles.

2. Evidence for reduced contaminant mobility from sorption, precipitation, and other binding processes. Assessment methods include solid-phase microextraction for hydrophobic chemicals and sequential extraction procedures for metals.

3. Evidence for chemical or biological transformations to less toxic forms. Here, a wide spectrum of methods for assessment and prognosis are available for contaminated sediments (Apitz et al. 2004).

Source control is critical to the success of any sediment remedy, including MNR. However, MNR is particularly sensitive to source control. Lack of understanding and management of sources can compromise the ability to monitor and quantify MNR processes and can limit the effectiveness of the remedy itself if natural recovery rates are outpaced by ongoing releases (Magar et al. 2009).

MNR is one of the most mature and available management strategies for contaminated sediments (apart from environmental dredging and capping) under U.S. EPA's "Contaminated Sediment Remediation Guidance for Hazardous Waste Sites (Anonymous 2005). In 2004, the U.S. EPA decided to take action to clean up contaminated sediment at approximately 140 sites, including federal facilities, under the Comprehensive Environmental Response, Compensation, and Liability Act (commonly known as Superfund) and additional sites under the Resource and Recovery Act. Many other sites are being cleaned up under state authorities, other federal authorities, or as voluntary actions (Anonymous 2005). Capping, either 
alone or in combination with removal and/or MNR, is planned or has been implemented at about 40 sediment remediation projects in the USA whereas MNR as a primary remedy, or in combination, is a component of about 28 projects in the USA (Förstner and Apitz 2007).

In Europe, several regulatory frameworks such as EU Landfill Directive, EU Waste Catalogue, EU Soil Strategy (or Framework Directive) and Marine Strategy Directive must be considered alongside the WFD. One of the consequences of this complexity seems to be that in Europe there is less regulatory acceptance to risk-based (rather than mass-based or chemical threshold-based) decisions, and thus more resistance to some of the technologies favoured by the US Environmental Protection Agency (Förstner and Apitz 2007).

Table 4 presents examples of JSS articles from coordinated research programmes on near-natural remediation of contaminated sediments and fluvisols.

In the German KORA-Programme (Retention and Degradation Processes Reducing Contaminants in Groundwater and Soil (BMBF 2002-2006)), was a research project specifically devoted to the assessment of highly polluted floodplain soil ("fluvisol") based on national guideline values and monitored natural attenuation criteria (Schwartz et al. 2006). Guidelines were developed on "Natural pollutant reduction processes" for (a) fluvisols and (b) sediments, including proposals for geochemicalecotoxicological assessment schemes for fluvisols (Gerth in Hoth et al. 2008):

1. Total concentrations, for example, according to German Soil Protection and Contaminated Sites Ordinance;
2. leachate concentrations, following the leachate prognosis (column elution), as developed for the German Soil Protection and Contaminated Sites Ordinance;

3. ecotoxicity test procedures involving tests on habitat functions for effect indication of all present pollutants; and

4. bioavailability and binding stability, (1) solid-phase microextraction and (2) sequential extraction procedure for inorganic pollutants.

In order to indicate a sufficient retention potential, the first three criteria should be fulfilled. The criterion "total concentration" may fail, if there is a strong fixation of the pollutants; this case demonstrates the effect of natural attenuation processes.

One of the major outcomes of this study is that for the Bitterfeld floodplain case, as probably for many other examples, the main problem for the dissemination of pollutants is not chemical stability of the fluvisol but rather the mechanical dispersion of the relatively mobile sediments in the flood channel network.

Phytoremediation (No. 11 in Table 4) is an emerging technology based on the use of green plants to remove, contain, inactivate or destroy harmful environmental pollutants. Similar to the experience with MNR and capping approaches, the developments are different on both sides of the Atlantic (Schwitzguébel et al. 2002): In Europe, phytoremediation has primarily been research-driven and, based on the outcomes, applications have been envisaged. By contrast, the approach in the USA is more application driven. In spite of a growing track record of commercial success, more demonstration projects are needed to prove that

Table 4 JSS articles from coordinated research programmes on near-nature remediation of contaminated sediments and fluvisols

\begin{tabular}{|c|c|c|c|}
\hline & Programme & Title and Authors & $\begin{array}{l}\text { JSS } \\
\text { number }\end{array}$ \\
\hline $7^{\mathrm{a}}$ & PGBO-NL (1996-1999) & $\begin{array}{l}\text { "Ripening of clayey dredged sediments during temporary upland disposal-a } \\
\text { bioremediation technique" by Vermeulen et al. (2003) }\end{array}$ & $3: 49-59$ \\
\hline $8^{\mathrm{b}}$ & $\begin{array}{l}\text { ConSed SUBAD-ABS Australia-D } \\
\text { (1998-2003; BMBF) }\end{array}$ & $\begin{array}{l}\text { "Managing contaminated sediments. IV Subaqueous storage and capping of dredged } \\
\text { material", Jacobs and Förstner (2001); "Monitoring of subaqueous depots with active } \\
\text { barrier systems for contaminated dredged material using dialysis samples and DGT } \\
\text { probes" by Jacobs (2003) }\end{array}$ & $\begin{array}{l}1: 205- \\
212 \\
3: 100- \\
107\end{array}$ \\
\hline $9^{c}$ & KORA-D (2002-2006; BMBF) & $\begin{array}{l}\text { "Assessment of highly polluted fluvisol in the Spittelwasser floodplain based on national } \\
\text { guideline values and MNA-criteria" by Schwartz et al. (2006) }\end{array}$ & $\begin{array}{c}6: 145- \\
155\end{array}$ \\
\hline $10^{\mathrm{d}}$ & US SERD Programme & $\begin{array}{l}\text { "Characterization of contaminant migration potential in the vicinity of an in-place sand cap" } \\
\text { by Merritt et al. (2010) }\end{array}$ & $\begin{array}{l}10: 440- \\
450\end{array}$ \\
\hline 11 & Phytoremediation & $\begin{array}{l}\text { European and American trends: successes, obstacles and needs by Schwitzguébel et al. } \\
(2002)\end{array}$ & 2:91-99 \\
\hline 12 & Constructed Wetlands (examples) & $\begin{array}{l}\text { Treatment of organic pollutants (case studies in Austria, Germany, Italy, Portugal, } \\
\text { Switzerland and USA by Haberl et al. (2003) }\end{array}$ & $\begin{array}{c}3: 109- \\
124\end{array}$ \\
\hline
\end{tabular}


phytoremediation is effective in order to rigorously measure its underlying economics, and to expand its applications.

Constructed wetlands (No. 12 in Table 4) are wetlands designed to improve water quality. Wetlands can be defined as ecosystems that depend on constant or recurrent, shallow inundation or saturation at or next to the surface of the substrate. The major wetland components are (Haberl et al. 2003):

- Vegetation. The prevalent vegetation consists of macrophytes that are typically adapted to areas having hydrologic and soil conditions described in the definition.

- Soil. Soils are present and have been classified as hydric, or they possess characteristics that are associated with reducing soil conditions.

- Hydrology. The area is inundated either permanently or periodically at mean water depth of $<2 \mathrm{~m}$, so the soil is saturated to the surface at some time during the growing season of the prevalent vegetation.

The constructed wetland technology is mature and tested. The Interstate Technology and Regulatory Council has prepared a "Guidance Document for Constructed Treatment Wetlands" (Anonymous 2003). This document provides detailed descriptions of the various contaminant treatment objectives, treatment efficiencies, and goals of different constructed wetland applications; detailed, sitespecific pre-design criteria and conceptual designs are outlined, followed by final design, post-construction activities, operation and maintenance and implementation costs.

\section{Case studies}

The various topics from the preceding sections will be illustrated by two case studies. The first one deals with the Port of Rotterdam which is located in the Rhine-Meuse estuary and is the largest harbour in Europe. This is a case study on 40-years' research carried out by an agency which is downstream of many point and diffuse pollutant sources in the catchment. The second one illustrates the case of a single, large-scale polluted site which affects the sediment quality downstream in the catchment (Elbe).

\subsection{Case study I: Port of Rotterdam - a history of dredged material disposal}

The port of Rotterdam is located in the Rhine-Meuse estuary and is the largest port in Western Europe. Its geographical location - on the North Sea and Rhine and Meuse estuaries - involves significant transport and settling of marine and fluvial sediments. Marine sediments accumulate through tidal action mainly in the western port areas, whereas the eastern port areas are mainly influenced by fluvial sediments. Most of the sediment to be dredged derive from the marine environment and only around half of the river sediment settles in the port. The total amount of dredged material is 15 to 20 million $\mathrm{m}^{3} /$ year. Until the 1970 s, the way in which the dredged material was handled was mainly determined by the method of dredging used, the costs and its possible uses (Nijssen 1988). About half was relocated on the coast and the remainder was used for raising sites for the extension of the city or agricultural purposes. However, concerns were raised over its agricultural use and potential impacts on the marine environment; thus already in 1975 a regional committee was set up in order to develop a policy to solve the problems relating to the discharge of dredged material (Nijssen 1988).

Depending upon its designation as uncontaminated (Western port area) or lightly contaminated and heavily contaminated (Eastern port area), dredged material had to be disposed of at sea at a large-scale site or at a specially designed site. The relocation of this dredged material to the North Sea, the preferred disposal option, is regulated by a set of chemical criteria, the so-called Sea/Slufter limits. Dredged material exceeding these limits, mainly sediments from the eastern port areas (and partly from the Botlek area), has to be disposed of in a confined site, the Slufter. However, most of the dredged material is currently returned to where it came from: the sea. This is possible due to large decreases in concentrations of contaminants since 1975.

\subsubsection{POR I and POR II}

Since the contamination of the river sediment became apparent in the 1970s, the Rotterdam Dredged Material Management Programme has been strongly focused on the control of the initial sources of contamination, by way of the Rhine Research Project. Agreements were successfully reached with all major discharging companies concerning a radical reduction in their discharges. Over the past 15 years, this approach has led to a significant reduction in point discharges and resulted in a significant improvement with regard to the quality of the Rhine water and consequently to the quality of the dredged material in the port of Rotterdam. However, not all targets were met and, in addition, the "Slufter" had a limited storage capacity. These developments made it necessary to start the "Rhine Research Project II" in 2000. The main objective of the "Rhine Research Project II" was to assess the probable quality of Rhine sediment in 2015 in view of existing and upcoming legislation. The question raised was how the contamination of dredged material will develop in the future and whether it will reach levels that allow relocation to the North Sea.

As part of this study an inventory was made of point and diffuse sources in the Rhine catchment for several time periods; this showed a large reduction in the contributions 
of point sources to the total contaminant load. Diffuse sources (groundwater, urban runoff, soil erosion etc.) on the other hand became relatively more important over time and presently contribute more than $70 \%$ of the total load (Vink and Behrendt 2002).

Two types of scenarios were assessed with a model for the period up to 2015 (Gandrass and Salomons 2001). The "business as usual" scenarios take measures into account that are already agreed upon or are "in the pipeline", i.e. the implementation that can most probably be expected. The "Green" scenarios consider additional reduction measures that might be realised but largely depend on hypothesised policies (Fig. 1a).
Taking the present state as a starting point, the changes in modelled future inputs to the Rhine basin were used to extrapolate the development of the quality of sediments in eastern parts of the Port of Rotterdam; these were then compared to current Dutch quality criteria for the relocation of dredged material to the North Sea (see Fig. 1b).

The main conclusion which can be drawn from this study is that although legislation and agreements are responsible for large reductions in point sources, difficulties in controlling diffuse sources ("legacies of the past") remain; they are now the main culprits for water and sediment quality. A further analysis of the data, and in particular the relationship between discharge, showed an inverse relationship to the one observed
Fig. 1 a Results of the scenario analysis for zinc and benzo(a) pyrene inputs in the Rhine basin upstream Bimmen/Lobith (from Gandrass and Salomons 2001). b Present (2000) and estimated future (2015) quality of dredged material in the eastern parts of the port of Rotterdam according to current Dutch criteria (from Gandrass and Salomons 2001) a

Examples for measures that had been taken into account in the BAU and Green scenarios

Urban areas: Decoupling of paved areas from the sewer system and enlargement of rainwater storage basins (Green). Active replacement of building materials as uncoated galvanised steel, copper and lead (Green).

Erosion: Infrastructural measures in agriculture (Green).

Waste water treatment plants (WWTPs): All WWTPs of category 3 include a denitrification step and WWTPs of category 4 a P-elimination step (BAU). Phophorus-elimination in WWTPs of category 3 and microfiltration in largest (category 5) WWTPs (Green).

Industry: Application of 'best available techniques' (BAT) with regard to emissions to rivers and atmosphere (Green and/or BAU).

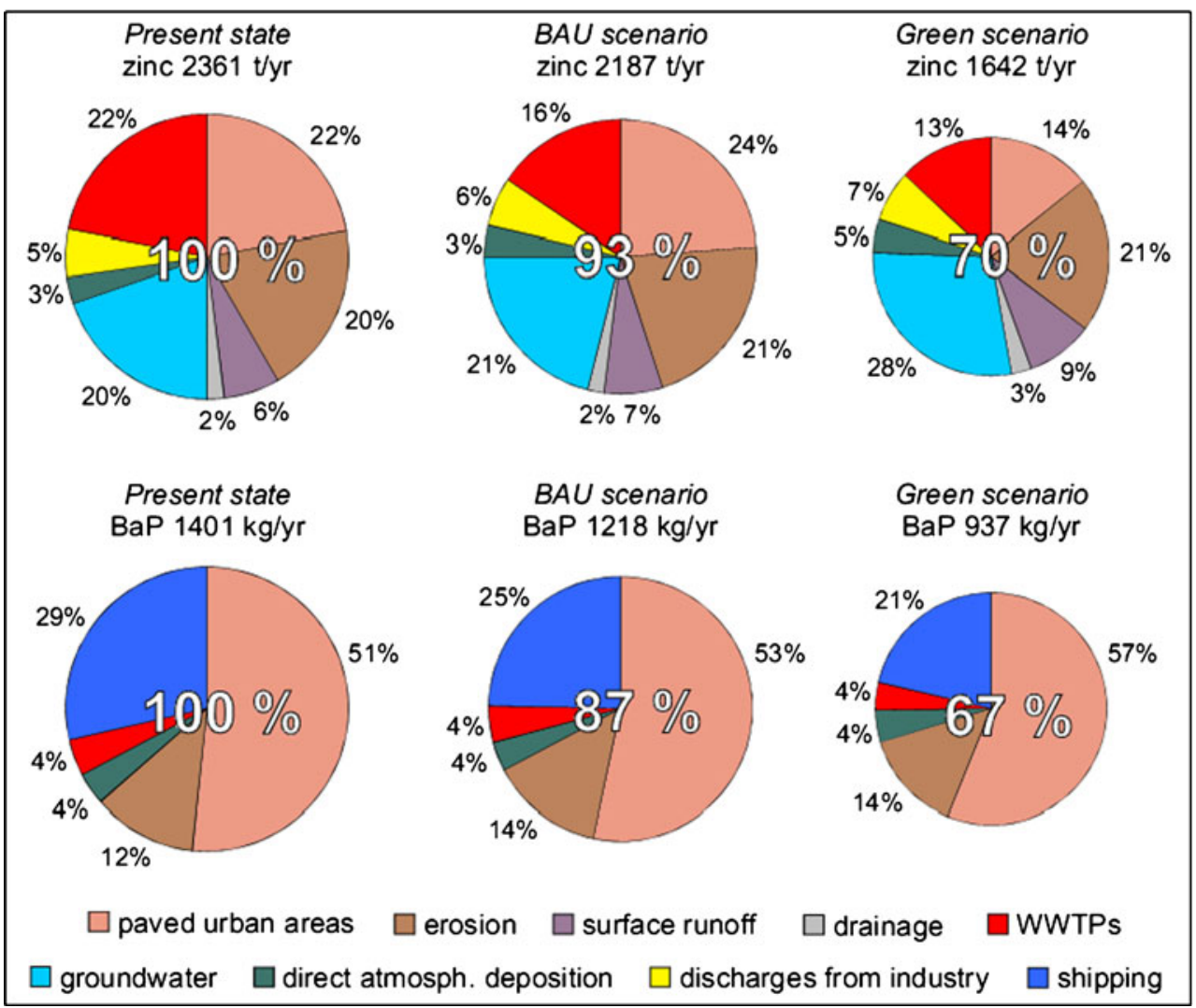


Fig. 1 (continued)

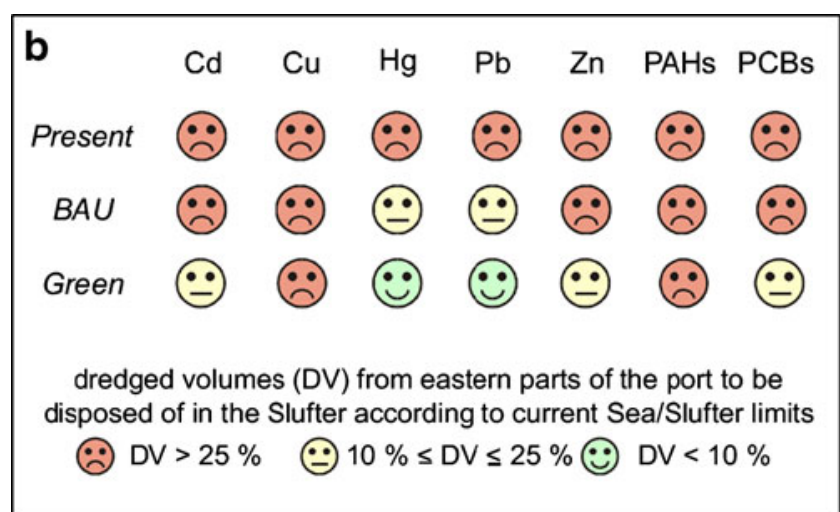

CTT values in the Port upon re-suspension of the sediment, and (3) the potential for re-suspension. CTT stands for "Chemistry-Toxicity Test"; these actions levels are set by the Dutch authorities for the permit to relocate dredged material from Rotterdam harbour to the North Sea (Stronkhorst 2003). The potential for re-suspension was considered in terms of the hydrological situation and was based upon measurements of erosion potentials and observations of increased contaminated solid matter downstream of the site (Table 5).

The "success" of the POR III study, particularly in its observation of a clear connection between two critical HCB source areas and the expected effects on the sediment quality of the target area, was due to the relatively simple hydrological situation and the existence of large data sets including measurements of suspended matter and critical priority concentrations/loads over several flood cycles along the main course of the Rhine (1) the hazard class of the site, (2) the capability to exceed

Table 5 "Areas of risk" in the Rhine basin and selected tributaries, concluded from evidence of theoretical possibility to exceed the CTT level (see text; discharge level) and indication of re-suspension (hydrological situation)

\begin{tabular}{|c|c|c|c|c|c|}
\hline \multicolumn{2}{|c|}{ Theoretical exceedance of CTT upon sediment re-suspension } & \multicolumn{3}{|c|}{ Indication of re-suspension } & \multirow{2}{*}{$\begin{array}{l}\text { Risk for the port } \\
\text { of Rotterdam }\end{array}$} \\
\hline Area/Substance & Discharge level ${ }^{\mathrm{a}}$ & $\begin{array}{l}\text { Hydrological } \\
\text { situation }^{\mathrm{b}}\end{array}$ & Erosion potential $^{\mathrm{c}}$ & Increase in SPM load $^{\mathrm{d}}$ & \\
\hline \multicolumn{6}{|l|}{ Ruhr river } \\
\hline Polycyclic Aromatic Hydrocarbons (PAHs) & $\begin{array}{l}\text { MQ ( 20 mg/L), } \\
\text { MHQ ( 150 mg/L), } \\
\text { HHQ ( 250 mg/L) }\end{array}$ & $\begin{array}{l}\mathrm{BAU} \\
\mathrm{HQ}_{10} \\
\mathrm{HQ}_{100}\end{array}$ & $\begin{array}{l}+ \\
++ \\
+++\end{array}$ & $+\left(\mathrm{HQ}_{1}\right)$ & $\begin{array}{l}\text { No risk } \\
\text { Risk } \\
\text { High risk }\end{array}$ \\
\hline \multicolumn{6}{|l|}{ Higher and Upper Rhine barrages } \\
\hline Hexachloro-benzene (HCB) & MQ ( 20 mg/L) & $\begin{array}{l}\mathrm{BAU} \\
>\mathrm{HQ}_{1} \\
>\mathrm{HQ}_{10} \\
>\mathrm{HQ}_{50}\end{array}$ & $\begin{array}{l} \pm \\
+ \\
++ \\
+++\end{array}$ & $\begin{array}{l}+ \\
+++\end{array}$ & $\begin{array}{l}\text { Risk } \\
\text { High risk } \\
\text { High risk } \\
\text { High risk }\end{array}$ \\
\hline
\end{tabular}

From Heise and Förstner (2006)

${ }^{a}$ Discharge level: mean water discharge (MQ), mean flood discharge (MHQ), highest experienced discharge (HHQ))

${ }^{\mathrm{b}}$ Hydrological situation: business as usual conditions (BAU), flood return period $\left(\mathrm{HQ}_{x}\right.$ (where " $x$ " indicates the frequency of years with which such a high water is expected))

c,d \pm no obvious effect, + small effect, ++ significant effect, +++ large effect 
River. In more complex situations involving strongly varying water discharges in smaller tributaries, such as in floodplains, the assessment of erosion risks will require significantly more instrumental/experimental efforts and specific considerations of uncertainties.

4.2 Case study II: Bitterfeld—a "classical" site in the Elbe basin

The Spittelwasser site in the so-called Chemistry Triangle of the upper Elbe River system became a synonym for a complex situation, where contaminated sediments are dispersed on the catchment area scale. Approximately $60 \mathrm{~km}^{2}$ of lowland area downstream of the Spittelwasser creek northeast from Bitterfeld-Wolfen are strongly affected by pollutants such as HCH isomers, DDT and dioxins (Walkow 1996). The Spittelwasser acts as a flood channel of the lower Mulde River, when the water discharge in this Elbe tributary exceeds a 5 years return flood level $\left(\mathrm{HQ}_{5}\right)$ (Lindemann 2000). Dioxin pollution originates from processes such as magnesium production and can be traced down the Elbe system up to Hamburg harbour $(300-\mathrm{km}$ distance from the source) and to the North Sea (Götz et al. 1996). The dioxin inputs constitute a special environmental problem in the Elbe river basin, with high dioxin levels in feed and food from riparian floodplains (Netzband et al. 2007) and these highly toxic substances will play an important role in the proposed Marine Strategy Directive (Anonymous 2008). The Bitterfeld-Spittelwasser case is, therefore, an acid test for the implementation of the WFD in the Elbe River basin, i.e. to find a balance of interest with the downstream recipients of a severe pollution problem.

\subsubsection{Spittelwasser 2000}

The Spittelwasser area was chosen by the organisers of the international conference ConSoil 2000 for a case comparison and four expert teams from Denmark, Germany, the
Netherlands and the UK were invited. Evaluation of the plan was done by members of the networks of Network for Industrial Contaminated Land and the Contaminated Land Rehabilitation Network (Anonymous 2000b).

In the study of the German team (Förstner et al. 2001) a stepwise approach combining monitoring techniques and remediation measures to be used for contaminated floodplain areas was identified by the environmental authorities. This approach provides for point excavations of critical material and also for the installation of sediment traps. It also includes the promotion of plant growth to stabilize the soils and sediments and to support evapotranspiration (Table 6). The plan for a pilot or test study on a part of the floodplain area was scheduled for a 4-year implementation period and 15 years for after-care and was calculated to initially cost 2.2 million EUR, not including the costs for sediment traps, excavations and wetland construction (which would exceed the other costs by one to two orders of magnitude).

\subsubsection{Spittelwasser 2010: science}

The Bitterfeld-Spittelwasser area was revisited on the occasion of the Competitive Dialogue (a new form of contracting particularly complex projects in the European Procurement Law) on "Reduction of Sediment-associated Pollutant Loads in the Spittelwasser" in the State of Saxony-Anhalt's activities under the River Basin Management Plan of the FGG Elbe. From the involvement in the first Spittelwasser case study of 2000 and from the experience of the various research projects during the last decade - including the SEDYMO and KORA programmes - the concept "Spittelwasser 2010" could be envisioned as three major steps (Fig. 2, right side):

1. Source sanitation. Extraction of approximately a $20,000 \mathrm{~m}^{3}$ dioxin hot spot sediment from the Spittelwasser creek. The feasibility study from 1993 (Anonymous 1993) is still relevant and with the more recent

Table 6 Bitterfeld case study - stepwise implementation of a combination of monitoring systems, technical measures, testing devices, operation and after-care (Förstner et al. 2001)

01 Monitoring System Flood-dependent pollutant transport behaviour hydromechanical 400,000 EUR, 01st-48th month methods and air-based systems

02 Regulation Project Models for sediment and pollutant transport

Projects (1)+(3), 530,000 EUR, 12th-30th month

Sediment traps; point excavation of soil

Natural attenuation; promotion of plant growth

03 Testing

Functionality and the effects of sediment traps. Results used for 250,000 EUR, 30th-40th month predicting the pollutant output

04 Permanent operation Efficiency control of complete implementation, e.g. by GIS Establishment of citizens' bureau

05 Efficiency control The after-case shall be carried out continuously long-term as other permanently observed areas

770,000 EUR, 24th-48th month

225,000 EUR, $\sim 15$ years 


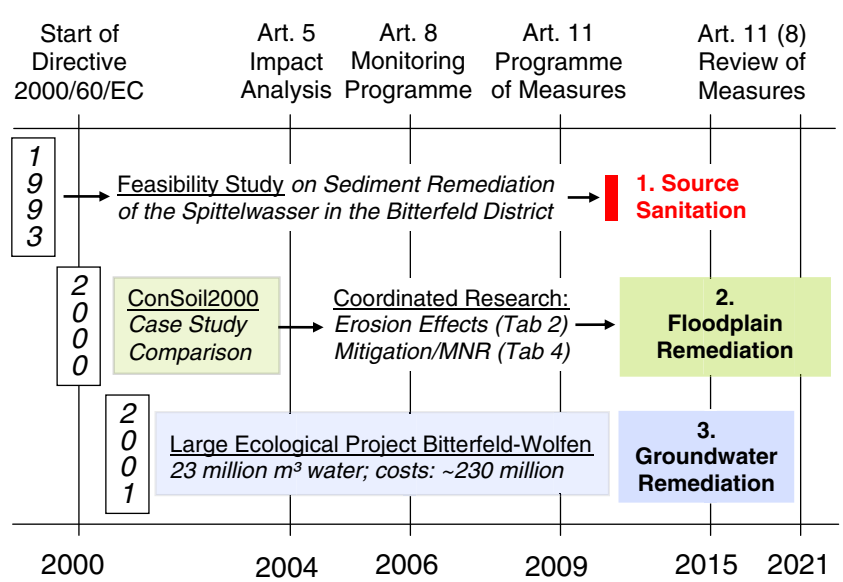

Fig. 2 Scheme of the development of an integrated remediation concept for large-scale historical sediment contamination, Spittelwasser in the Bitterfeld District, Germany. Left side "prerequisites": (1) feasibility study from July 1993 (Anonymous 1993); (2) ConSoil2000 Case Study Comparison (Anonymous 2000b) and Research programmes 2002-2010 (examples of JSS articles, Tables 2 and 4 (MNR monitored natural recovery)); (3) left side below, treated volume and expenses (in EUR) in ÖGP Bitterfeld-Wolfen until 2009. Right, Spittelwasser 2010 (see text). 1 Source sanitation, preferably excavation; 2 flood plain remediation; and 3 groundwater remediation. Time scale is the stepwise implementation of the EU Water Framework Directive (Anonymous 2000a)

technical developments, e.g. for a new pump and press system, the loss of contaminated sediments during extraction could be minimised.

2. Floodplain remediation, concerning a few tens of $\mathrm{km}^{2}$ of stable soils ("fluvisols") and erodible channel sediments by new technologies such as MNR and capping, bioremediation and phytoremediation, embedded into a runoff control system (wetland approach in the widest sense).

3. Groundwater remediation, including innovative in situ treatment techniques, in continuation of the former activities of Landesanstalt für Altlastenfreistellung (LAF) and its associated consultants; since 2009 monitored natural attention processes for groundwater remediation have been studied in the Ökologisches Großprojekt (ÖGP) Bitterfeld-Wolfen. In the context of the floodplain remediation (step 2), issues of water dynamics in a vertical-flow constructed wetland (step 2) have to be considered (see Fig. 2).

\subsubsection{Spittelwasser 2010: policy}

Twenty years after the German re-unification there is still an open controversy on the Bitterfeld-Spittelwasser site between Saxony-Anhalt and the downstream Federal States such as Lower Saxony and Hamburg. Within the common frame of the Large Ecological Project Bitterfeld-Wolfen
(ÖGP Bitterfeld-Wolfen), the managing agency LAF of Saxony-Anhalt has spent 230 million EUR in the period 2001 to 2010 for ground water sanitation, but any responsibility for sediment issues was rejected; the Competitive Dialogue was blocked by the LAF of SaxonyAnhalt. In this situation, the installation of an expert group on sediment management by the International Commission of the Protection of the Elbe can be taken as a positive sign, especially in the view of the work done by responsible river basin community (FGG Elbe) in the preparation of the River Basin Management Plan of the German Part of the Elbe catchment area (section 2.2). We expect that this expert group will confirm the state-of-the-art for sediment remediation in an early meeting, i.e. the source-firstprinciple, in that to the dioxin "hot spot" deposits of the Spittelwasser creek should be eliminated with high priority.

The State of Saxony-Anhalt is still in a relatively comfortable position for financing the Spittelwasser remediation project. With a general agreement in place since 2001, the German Federal Government was acquitted of its obligations by paying a lump sum of 1 billion EUR and the state of Saxony-Anhalt took over the sole responsibility for the remediation of contaminated sites. According to an interview with the managing director on the occasion of 10th anniversary of LAF, 830 million EUR are still available for future tasks. Taking $25 \%$ of the actual LAF budget, the Large Ecological Project Bitterfeld-Wolfen could operate the integrated Spittelwasser programme with approximately 10-15 million EUR for source sanitation (step 1), and approximately 200 million EUR for the steps 2 and 3 , in order to remediate one of the most spectacular contaminated sites in the Elbe basin, perhaps in the whole of Europe.

\section{Conclusions and outlook}

To start off: it is easier to draw conclusions on the directions of research over decades compared to a short period of 10 years. One thing is quite clear: science has become a partner in policy (at least in Europe). In particular the ample policy-oriented research funding by DG Research of the European Union had a large influence on the topics which have been addressed in our sediment research over the past decade. Furthermore, national governments have mimicked this approach in their funding. As this review shows, many advances have been made in the applied aspects of sediment pollution research, in particular, those dealing with management, clean up and legislation (e.g. bio-assays). This area will remain challenging in the future.

As we could have shown, as a result of the EU funding, a rapidly increasing number of institutions have produced work of great quality and novelty in new fields of sediment 
research and technology; thus Europe can compete well with leading research-groups world-wide. We hope, in return, that this will render our young and ambitious journal attractive for high-level manuscripts from these authors.

Acknowledgements Firstly, with regard to this review we want to thank Phil Owens and Sabine Apitz for their comments. Secondly, with regard to the decade of JSS, our thanks are due to Almut Heinrich and Moira Ledger as managing editors and last but not least Paul Roos who was instrumental in guiding the journal into the Springer family.

\section{References}

Ahlf W, Feiler U, Heininger P, Heise S (2008) Monitoring sediment quality using toxicity tests as primary tools for any risk assessment. In: Quevauviller P, Borchers U, Thompson C, Simonart $\mathrm{T}$ (eds) The water framework directive-ecological and chemical status monitoring, Chap. 6.2. Wiley, Chichester, UK, pp 255-269

Alexander M (2000) Aging, bioavailability, and overestimation of risk from environmental pollutants. Environ Sci Technol 34 (20):4259-4265

Anonymous (1993) Feasibility study on sediment remediation of the Spittelwasser in the Bitterfeld District (in German). UBS Schwerin, IGB-VT Hamburg on behalf of the Bitterfeld District Office, July 1993

Anonymous (1997) Contaminated sediments in port and waterwaysclean-up strategies and technologies. NRC, Marine Board, Committee on Contaminated Marine Sediments. Washington, DC, National Academy. p 295

Anonymous (2000a) Directive 2000/60/EC of the European Parliament and the Council of 23 October 2000 establishing a framework for Community action in the field of water policy (Water Framework Directive). Official Journal of the EC, L327

Anonymous (2000b) Bitterfeld/Spittelwasser site case study. Comparison of solutions for a large contamination based on different national policies. ConSoil 2000, 7th Int FZK/TNO Conference on Contaminated Soil in Cooperation with UFZ. p 168

Anonymous (2001a) SedNet-Initiative-Demand Driven, European Sediment Research Network-SedNet. Proposal No. EVK2001-00058 to EU Key Action 1 "Sustainable Management and Quality of Water", 1.4.1 "Abatement of water pollution from contaminated land, landfills and sediments. February 15, 2001

Anonymous (2001b) Programme plan. Mitigation of the environmental impact from mine waste (MiMi) for the period 2001-2003. Stockholm, February 2001, ISBN 91-89350-12-X

Anonymous (2003) Technical and regulatory guidance document for constructed treatment wetlands. Prepared by The Interstate Technology and Regulatory Council Wetlands Team. Washington, DC. Available at: www.itrcweb.org. Accessed 2 Oct 2010

Anonymous (2004a) Synthesis of the SedNet Work Package 2-5 outcome. J Soils Sediments 4:219-238

Anonymous (2004b) Opinion of the Scientific Committee on Toxicity, Ecotoxicity and th Environment (CSTEE) on 'The setting of environmental quality standards for thje priority substances included in Annex X of Directive 2000/60/EC in accordance with Article 16 thereof'. Adopted by the CSTEE during the 43rd plenary meeting of 28 May 2004. p 32

Anonymous (2004c) Agenda item 5: emission sources and controls for priority substances (including comments on the proposed quality standards for specific substances). Concept paper from 8 June 2004. Expert Advisory Forum on Priority Substances and
Pollution Control, 7th EAF Meeting, Brussels, 14-15 June 2004. p 77

Anonymous (2005) Contaminated sediment remediation guidance for hazardous waste sites. EPA-540-R-05-012, Office of Solid Waste and Emergency Response, Washington, DC

Anonymous (2007) Second five-year review report for the Wyckoff/ Eagle Harbor Superfund Site Bainbridge Island, Washington. Prepared by US Army Corps of Engineers for US Environmental Protection Agency, Region 10. September 26, 2007

Anonymous (2008) Directive 2008/56/EC of the European Parliament and of the Council of 17 June 2008 establishing a framework for community action in the field of marine environmental policy (Marine Strategy Framework Directive). Official Journal of the European Union, L 164/19-164/40

Apitz SE, Power B (2002) From risk assessment to sediment management: an international perspective. J Soils Sediments 2 (2):61-66

Apitz SE, White S (2003) A conceptual framework for river-basinscale sediment management. J Soils Sediments 3:132-138

Apitz SE, Ayers B, Kirtay VJ (2004) The use of data on contaminant/ sediment interactions to streamline sediment assessment and management, technical report 1918. San Diego, CA: SPAWAR Systems Center, San Diego. p 122

Apitz SE, Davis JW, Finkelstein K, Hohreiter DW, Hoke R, Jensen RH, Jersak J, Kirtay VJ, Mack EE, Magar VS, Moore D, Reible D, Stahl RG (2005) Assessing and managing contaminated sediments: part II, evaluating risk and monitoring sediment remedy effectiveness. Integr Environ Assess Manage 1:e1-e14. doi:10.1897/IEAM 2004a-002e.1

Apitz SE, Carlon C, Oen A, White S (2007) Strategic framework for managing sediment risk at the river basin and site-specific scale. In: Heise S (ed) Sustainable management of sediment resources: sediment risk management and communication, Chap 3. Elsevier, Amsterdam, pp 233-247

Barcelo D, Petrovic M (eds) (2006) Sustainable management of sediment resources, vol. 1. Sediment quality and impact assessment of pollutants. Elsevier, Amsterdam. p 386

Bortone P (ed) (2006) Sustainable management of sediment resources, vol. 2. Sediment and dredged material treatment. Elsevier, Amsterdam. p 222

Brils J (2004) Sediment monitoring under the EU water framework directive. J Soils Sediments 4:72-73

Ellen GJ, Gerrits L, Slob FL (2007) Risk perception and risk communication. In: Heise S (ed) Sustainable management of sediment resources: sediment risk management and communication, Chap 7. Elsevier, Amsterdam, pp 77-106

Förstner U (2002) Editorial: sediments and the European Water Framework Directive. J Soils Sediments 2:2-3

Förstner U (2009) Sediments and priority substances in river basins; new Directive 2008/105/EC; sediment issues in management plans. J Soils Sediments 9:89-93

Förstner U, Gerth J (2001) Natural attenuation-non-destructive processes. In: Stegmann R, Brunner G, Calmano W, Matz G (eds) Treatment of contaminated soil-fundamentals, analysis, applications, Chap 35. Springer, Berlin, pp 567-586

Förstner U, Apitz SE (2007) Sediment remediation: U.S. focus on capping and monitored natural recovery. J Soils Sediments 7 (6):351-358

Förstner U, Gerth J, Lindemann M, Wittmann U (2001) Managing contaminated sediments-III. In-situ sediment treatment (Spittelwasser case study). J Soils Sediments 1(3):181-187

Förstner U, Heise S, Ahlf W, Westrich B (2008) Data quality assurance of sediment monitoring. In: Quevauviller P, Borchers U, Thompson C, Simonart $\mathrm{T}$ (eds) The water framework directive-ecological and chemical status monitoring, Chap. 8.2. Wiley, Chichester, UK, pp 371-386 
Gandrass J, Salomons W (2001) Dredged material in the Port of Rotterdam-interface between the Rhine catchment and North Sea. GKSS Report. Available at: http://coast.gkss.de/aos/ dredged_material/. Accessed 2 Oct 2010

Götz R, Steiner D, Friesel P, Roch K, Walkow F, Maas V, Reincke H (1996) Dioxin in the River Elbe - investigations of their origin by multivariate statistical methods. Organohalog Compound $27: 440-443$

Gunn J, Noble BF (2009) Integrating cumulative effects in regional strategic environmental assessment frameworks: lessons from practice. J Environ Assess Policy Manag 11:267-290

Haberl R, Grego S, Langergraber G, Kadlec RH, Cicalini A-R, Martins Dias S, Novais JM, Aubert S, Gerth A, Thomas H, Hebner A (2003) Constructed wetlands for the treatment of organic pollutants. J Soils Sediments 3(2):109-124

Heise S (ed) (2007) Sustainable management of sediment resources: sediment risk management and communication. Elsevier, Amsterdam. p 278

Heise S, Förstner U (2006) Risk from historical contaminated sediment in the Rhine basin. Water Air Soil Pollut Focus 6:625-636

Heise S, Förstner U, Westrich B, Jancke T, Karnahl J, Salomons W, Schönberger H (2004) Inventory of historical contaminated sediment in Rhine basin and its tributaries. Report on Behalf of the Port of Rotterdam. Hamburg/Stuttgart. p 225

Heise S, Krüger F, Baborowski M, Stachel B, Götz R, Förstner U (2008) Assessment of risks from particle bound substances in the Elbe river basin (in German). Commissioned by Hamburg Port Authority and River Basin Community (FGG) Elbe. Hamburg, May 2008 (Förstner U "Measures", pp 247-341). p 349

Höglund LO, Herbert HR (eds) (2004) Mitigation of the environmental impact from mining waste - performance assessment main report. Stockholm Dec 2004, ISBN 91-89350-27-8. p 354

Hoth N, Rammlmair D, Gerth J, Häfner F (2008) Leitfaden "Natürliche Schadstoffminderungsprozesse an großräumigen Bergbaukippen/-halden und Flussauensedimenten. Empfehlungen zur Untersuchung und Bewertung der natürlichen Quelltermminimierung“. Freiberg/Frankfurt, November 2008. p 124. ISBN-978-3-89746-098-X

Joziasse J, Heise S, Oen A, Ellen GJ, Gerrits L (2007) Sediment management objectives and risk indicators. In: Heise S (ed) Sustainable management of sediment resources: sediment risk management and communication, Chap 2. Elsevier, Amsterdam, pp 9-75

Klapper H (2002) Mining lakes: generation, loading and water quality control. In: Mudroch A, Stottmeister U, Kennedy C, Klapper H (eds) Remediation of abandoned surface coal mining sites. Springer, Heidelberg, pp 57-110

Lindemann M (2000) Das ökologische Großprojekt Bitterfeld-Wolfeneine Bilanz aus fachlicher Sicht. Altlasten Spektrum 10(4):205-214

Magar VS, Wenning RJ (2006) The role of monitored natural recovery in sediment remediation. Integr Environ Assess Manag 2(1):66-74

Magar VS, Chadwick DB, Bridges TS, Fuchsman PhC, Condor JM, Dekker TJ, Steevens JA, Gustavson KE, Mills MA (2009) Technical guide. Monitored natural recovery at contaminated sediment sites. Environmental Security Technology Certification Program, Project ER-0622, May 2009. p 276

Merkel B (2006) Long-term fate of uranium tailings in mountain areas. In: Merkel B, Hasche-Berger A (eds) Uranium in the environment. Springer, Berlin, pp 47-56

Middelkoop H, Erkens G, van der Perk M (2010) The Rhine delta - a record of sediment trapping over time scales from millennia to decades. J Soils Sediments 10:628-639

Mudroch A, Stottmeister U, Kennedy C, Klapper H (eds) (2002) Remediation of abandoned surface coal mining sites. Springer, Heidelberg. p 175
Netzband A et al (2007) Sediment management - an essential element of river basin management plans". J Soils Sediments 7:117-132

Nijssen JPJ (1988) Rotterdam dredged material: approach to handling. In: Salomons W, Förstner U (eds) Environmental management of solid waste-dredged material and mine tailings. Springer, Berlin, pp 243-281

Owens PN (2005) Conceptual models and budgets for sediment management at the river basin scale. J Soils Sediments 5:201-212

Owens PN (2008) Sustainable management of sediment resources: sediment management at the river basin scale. Elsevier, Amsterdam, p 264

Owens PN, Petticrew EL (2008) Book review. Bernd Westrich, Ulrich Förstner (eds) Sediment dynamics and pollutant mobility in riversan interdisciplinary approach. J Soils Sediments 8:151-153

Owens PN, Petticrew EL, van der Perk M (2010) Sediment response to catchment disturbances. J Soils Sediments 10:591-596

Petticrew EL (2009) Thirty years of sediment-water science: history, trends and future directions. Mar Freshwater Res 60 (7):611-618

Quevauviller Ph (2001) Harmonization, standardization for soils and sediment: fractionation studies and usefulness in assessment and risk management. J Soils Sediments 1:175-180

Quevauviller Ph, Borchers U, Thompson KC, Simonart T (eds) (2008) The water framework directive-ecological and chemical status monitoring. Wiley, Chichester, UK. p 476

Salomons W (2005) Sediments in the catchment-coast continuum. J Soils Sediments 5:2-8

Salomons W, Förstner U (1984) Metals in the hydrocycle. Springer, Heidelberg, p 349

Salomons W, Brils J (eds) (2004) Contaminated sediments in European river basins. European Sediment Research Network SedNet, EVK1-CT-2001-20002, Key-action 1.4.1 Abatement of water pollution from contaminated land, landfills and sediments. Co-ordinator Jos Brils, TNO, The Netherlands. December 29th, 2004. Available at: www.SedNet.org. Accessed 2 Oct 2010

Schwartz R, Gerth J, Neumann-Hensel H, Bley S, Förstner U (2006) Assessment of highly polluted fluvisol in the Spittelwasser floodplain based on national guideline values and MNAcriteria. J Soils Sediments 6(3):145-155

Schwitzguébel J-P, van der Lelie D, Baker A, Glass DJ, Vangronsveld J (2002) Phytoremediation: European and American trendssuccesses, obstacles and needs. J Soils Sediments 2:91-99

Slattery MC, Todd LM, Phillips JD, Breyer JA (2010) Holocene sediment accretion in the Trinity River delta, Texas, in relation to modern fluvial input. J Soils Sediments 10:640-652

Slaymaker O (2010) Drivers of mountain landscape change during the twenty-first century. J Soils Sediments 10:597-610

Stronkhorst J (2003) Ecotoxicological effects of Dutch harbour sediments. Ph.D. thesis, Free University of Amsterdam. p 202

Vanmaercke M, Zenebe A, Poesen J, Nyssen J, Verstraeten G, Deckers $J$ (2010) Sediment dynamics and the role of flash floods in sediment export from medium-sized catchments: a case study from the semi-arid tropical highlands in northern Ethiopia. J Soils Sediments 10:611-627

Vellinga T (2004) From dredged material management to sediment management. J Soils Sediments 4:215

Vink R, Behrendt H (2002) Heavy metal transport in large river systems: heavy metal emissions and loads in the Rhine and Elbe river basins. Hydrol Proc 16:3227-3244

Walkow F (1996) The dioxin pollution of Bitterfeld — site description. Lecture held on the meeting "Chemistry, man and environment", 20th Anniversary of the Seveso accident, Milan, October 1996 (reprinted in Anonymous (2000b))

Westrich B, Förstner U (eds) (2007) Sediment dynamics and pollutant mobility in rivers - an interdisciplinary approach. Springer, Heidelberg. p 483 